\title{
ANALISIS KEBUTUHAN INFORMASI STANDAR DI KAWASAN PUSPIPTEK SERPONG: BERDASARKAN JENIS DAN KLASIFIKASINYA
}

\author{
Rahartri \\ Pusat Data dan Dokumentasi Ilmiah - LIPI \\ Korespondensi: rahartris@yahoo.com
}

Diajukan: 14-10-2018; Direview: 23-10-2018; Diterima: 14-03-2019; Direvisi: 07-08-2019

\begin{abstract}
This study aims to find out the standard information needs in the Puspiptek Region. While the specific objective of this study is to know the types of standard and standard classification required. The study was carried out descriptively. The data were collected by inventorying standard information needs during the 2011-2017 period. The results of this study concluded: 1) the type of standard information needed in Puspiptek Serpong Area are ASTM, JIS, ISO, BS, SNI, DIN, IEC, UIC; 2) based on the classification, the standards needed in the Puspiptek Serpong area are: a) ASTM, miscellaneous material classification; miscellaneous subjects; cementious, ceramic, concrete, and masonry material; b) JIS, railway engineering classification; chemical engineering; mechanical engineering; c) ISO, rubber and plastic industries classification; metallurgy; road vehicles engineering; d) British standard, agriculture classification; construction materials and building; chemical technology; e) SNI, metallurgy classification; food technology; construction materials and building; f) DIN standard, rubber and plastic industries classification; paint and colour industries; g) IEC standard, electrical engineering classification; testing/ environmental testing. The results of this study can be the recommendations for decision makers in the context of procurement/provision of documents, especially standard documents in the Puspiptek Serpong, for the development of science and technology.
\end{abstract}

\begin{abstract}
ABSTRAK
Kajian ini bertujuan untuk mengetahui kebutuhan informasi standar di kawasan Puspiptek. Sedangkan tujuan khususnya adalah mengetahui jenis dan klasifikasi standar yang dibutuhkan. Kajian dilakukan secara deskriptif. Pengumpulan data dengan menginventarisasi kebutuhan informasi standar selama periode 2011-2017. Dari hasil kajian disimpulkan: 1) jenis informasi standar yang diperlukan di kawasan Puspiptek Serpong adalah ASTM, JIS, ISO, BS, SNI, DIN, IEC, UIC; 2) berdasarkan klasifikasinya, standar yang diperlukan di kawasan Puspiptek Serpong adalah: a) ASTM, klasifikasi miscellaneous material; miscellaneous subjects; cementious, ceramic, concrete, and masonry material; b) JIS, klasifikasi railway engineering; chemical engineering; mechanical engineering; c) ISO, klasifikasi Rubber and plastic industries; Metallurgy; Road vehicles engineering; d) standar British, klasifikasi agriculture; construction materials and building; chemical technology; e) SNI, klasifikasi metallurgy; food technology; construction materials and building; f) standar DIN, klasifikasi rubber and plastic industries; paint and colour industries; g) standar IEC, klasifikasi electrical engineering; testing/ environmental testing. Hasil kajian ini dapat menjadi masukan bagi para pengambil keputusan dalam rangka pengadaan/penyediaan dokumen khususnya dokumen standar di kawasan Puspiptek Serpong, dalam rangka pengembangan ilmu pengetahuan dan teknologi.
\end{abstract}

Keywords: Standard collection; Information need; User; Special library; Research institution

\section{PENDAHULUAN}

Pusat Penelitian Ilmu Pengetahuan dan Teknologi (Puspiptek) didirikan berdasarkan Keppres nomor 43/1976 tanggal 1 Oktober 1976, yang digagas oleh Menteri Riset RI (Prof. Dr. Sumitro Djojohadikusumo) dan dilaksanakan oleh Menteri Negara Riset dan Teknologi RI (Prof. Dr.Ing.B.J.Habibie (Wikipedia, 2018). Pendirian kawasan Puspiptek bertujuan untuk meningkatkan kelancaran pelaksanaan kegiatan di bidang penelitian ilmu pengetahuan dan 
teknologi (iptek). Peran kawasan ini dalam rangka pemenuhan kebutuhan informasi masyarakat ilmiah dan meningkatkan pengetahuan masyarakat umum di bidang iptek. Dalam rangka mendukung proses industrialisasi di Indonesia, Puspiptek dirancang untuk menjadi kawasan yang mensinergikan tenaga terdidik dan terlatih, peralatan penelitian dan pelayanan teknis yang paling lengkap di Indonesia, serta teknologi dan keahlian yanq telah terakumulasikan selama lebih dari seperempat abad (Wikipedia, 2018).

Di kawasan Puspiptek terdapat Unit Pelaksana Jasa (UPJ) Pusat Dokumentasi dan Informasi Ilmiah - Lembaga Ilmu Pengetahuan Indonesia (PDII - LIPI) yang berlokasi di Gedung Pusat Informasi atau Gedung 109 lantai 1 Kawasan Puspiptek Serpong - Tangerang Selatan. Keberadaan UPJ PDII-LIPI Serpong ini bertujuan untuk memberikan kemudahan layanan informasi bagi peneliti di kawasan tersebut. Sumber daya informasi yang tersedia di UPJ PDII LIPI Serpong yaitu koleksi umum, referensi, laporan penelitian, tesis dan disertasi, majalah terjilid dan lepas, paten, koleksi Teknologi Tepat Guna (TTG), dan dokumen standar (ASTM, JIS, ISO, BS, SNI, DIN, IEC, UIC).

Penelitian ini merupakan penelitian pertama terkait kebutuhan informasi standar di kawasan Puspiptek Serpong, karena sejak beroperasinya UPJ PDII-LIPI Serpong tahun 1993, belum pernah dilakukan kajian mengenai kebutuhan informasi standar di kawasan ini. Penelitian ini bertujuan untuk mengevaluasi kebutuhan informasi pengguna terhadap dokumen standar di kawasan Puspiptek Serpong. Adapun tujuan khusus penelitian untuk mengetahui: 1) jenis informasi standar; dan 2) klasifikasi standar yang diperlukan di kawasan Puspiptek Serpong. Hasil kajian ini diharapkan dapat meningkatkan layanan informasi di UPJ PDII-LIPI Serpong, khususnya layanan informasi standar; serta dapat memberikan masukan kepada pimpinan terkait dokumen standar yang akan diadakan.

\section{TINJAUAN PUSTAKA}

\subsection{Standar}

Standar adalah persyaratan teknis atau sesuatu yang dibakukan, termasuk tata cara dan metode yang disusun berdasarkan konsensus semua pihak/pemerintah/keputusan internasional yang terkait dengan memperhatikan syarat keselamatan, keamanan, kesehatan, lingkungan hidup, perkembangan iptek, pengalaman, serta perkembangan masa kini dan masa depan untuk memperoleh manfaat yang sebesar-besarnya (UU No.20 Tahun 2014 tentang Standardisasi dan Penilaian Kesesuaian). Sedangkan menurut International Organization for Standardization, standar adalah dokumen yang memberikan persyaratan, spesifikasi, pedoman atau karakteristik yang dapat digunakan secara konsisten untuk memastikan bahwa bahanbahan, produk, proses dan layanan yang cocok untuk tujuan mereka. Standar adalah ukuran tertentu yang dipakai sebagai patokan. Adapun standarisasi adalah penyesuaian bentuk (ukuran, kualitas, dsb.) dengan pedoman (standar) yang telah ditetapkan (KBBI, 2001).

\subsection{Informasi Standar}

Untuk mendukung pasar nasional dalam menghadapi proses globalisasi perdagangan, dipandang perlu untuk menyiapkan perangkat hukum nasional di bidang standardisasi yang tidak saja mampu menjamin perlindungan terhadap masyarakat khususnya di bidang keselamatan, keamanan, kesehatan, dan lingkungan hidup, tetapi juga meningkatkan pertumbuhan ekonomi nasional. Standardisasi dimaksudkan untuk meningkatkan perlindungan kepada konsumen, pelaku usaha, tenaga kerja, dan masyarakat lainnya baik untuk keselamatan, keamanan, kesehatan maupun pelestarian fungsi lingkungan hidup, serta untuk 
membantu kelancaran perdagangan dan mewujudkan persaingan usaha yang sehat dalam perdagangan (Peraturan Pemerintah RI No.102 Tahun 2000 tentang Standardisasi Nasional, 2000).

Standar memegang peranan penting untuk menciptakan produk yang bermutu, dapat memenuhi tuntutan pasar nasional dan internasional sehingga mampu menembus pasar dunia. Dengan standar, produk yang dipasarkan akan memiliki daya saing yang kuat. Standar juga diperlukan, khususnya dalam memantapkan dan meningkatkan daya saing produk, memperlancar arus perdagangan, dan melindungi kepentingan umum (BSN, 2018). Di dunia industri, standar sangat diperlukan dalam rangka mengantisipasi era globalisasi perdagangan dunia (Rahartri, 2017).

Standar menghasilkan manfaat ekonomi yang sangat besar. Di seluruh dunia, standar mempromosikan perdagangan, mendorong rasionalisasi, jaminan kualitas dan perlindungan lingkungan, serta meningkatkan keamanan dan komunikasi. Standar memiliki efek yang lebih besar pada pertumbuhan ekonomi daripada paten atau lisensi. Standar juga memainkan peran deregulasi, membebaskan negara dari tanggung jawab untuk mengembangkan spesifikasi teknis secara rinci. Dengan mengacu pada standar, peraturan perundangan lebih fleksibel dalam beradaptasi dengan kemajuan teknis (DIN - German National Standards, 2018).

\section{METODE}

Kajian ini bersifat deskriptif. Responden kajian adalah pengguna informasi standar di UPJ PDII - LIPI Kawasan Puspiptek Serpong tahun 2011 - 2017, yang terdiri dari peneliti, mahasiswa, masyarakat industri, dan pengguna lain. Pengumpulan data dilakukan dengan menginventarisasi kebutuhan informasi standar pengguna dalam periode tersebut. Data (kuantitatif) yang telah terkumpul diedit dan dientri dengan Microsoft Excel. Penjabaran data dalam bentuk tabulasi frekuensi dan grafik, berdasarkan jenis dan klasifikasi standar. Objek kajian ini adalah dokumen standar ASTM, JIS, ISO, BS, SNI, DIN, IEC, UIC. Data hasil pembahasan menjadi dasar kesimpulan kajian.

\section{HASIL DAN PEMBAHASAN}

\subsection{Kebutuhan Informasi Standar Berdasarkan Jenis Dokumen}

Dalam kurun waktu tahun 2011-2017, kebutuhan informasi standar pengguna di kawasan Puspiptek Serpong dapat dilihat pada Tabel 1.

Tabel 1. Kebutuhan Informasi Standar Pengguna di Kawasan Puspiptek Serpong

\begin{tabular}{|c|c|c|c|c|c|c|c|c|}
\hline \multirow{2}{*}{$\begin{array}{c}\text { Dokumen } \\
\text { Standar }\end{array}$} & \multicolumn{7}{|c|}{ Jumlah Permintaan (Judul) } & $\mathbf{2 0 1 4}$ \\
\cline { 2 - 9 } & $\mathbf{2 0 1 1}$ & $\mathbf{2 0 1 2}$ & $\mathbf{2 0 1 3}$ & $\mathbf{2 0 1 4}$ & $\mathbf{2 0 1 5}$ & $\mathbf{2 0 1 6}$ & $\mathbf{2 0 1 7}$ & Jumlah \\
\hline ASTM & 112 & 115 & 123 & 130 & 48 & 69 & 57 & 654 \\
\hline JIS & 30 & 56 & 25 & 39 & 19 & 156 & 62 & 387 \\
\hline ISO & 28 & 24 & 9 & 59 & 23 & 19 & 7 & 169 \\
\hline BS & 14 & & 2 & 25 & 2 & 105 & 11 & 159 \\
\hline SNI & 10 & 31 & 14 & 15 & 27 & 12 & 17 & 126 \\
\hline DIN & 2 & 1 & & 56 & & 1 & & 60 \\
\hline IEC & 47 & & & & & & 2 & 49 \\
\hline UIC & & & & 37 & 2 & & & 39 \\
\hline Standar lain *) & 36 & & 28 & 26 & 2 & 15 & 25 & 132 \\
\hline Jumlah & 279 & 227 & 201 & 387 & 123 & 377 & 181 & 1775 \\
\hline
\end{tabular}

Keterangan:

ASTM = American Society for Testing and Material

JIS $=$ Japanese Industrial Standards 


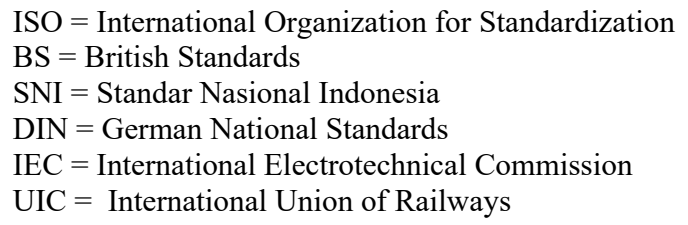

Data menunjukkan bahwa dokumen standar merupakan salah satu jenis informasi iptek yang banyak dicari oleh pengguna (Gambar 1).

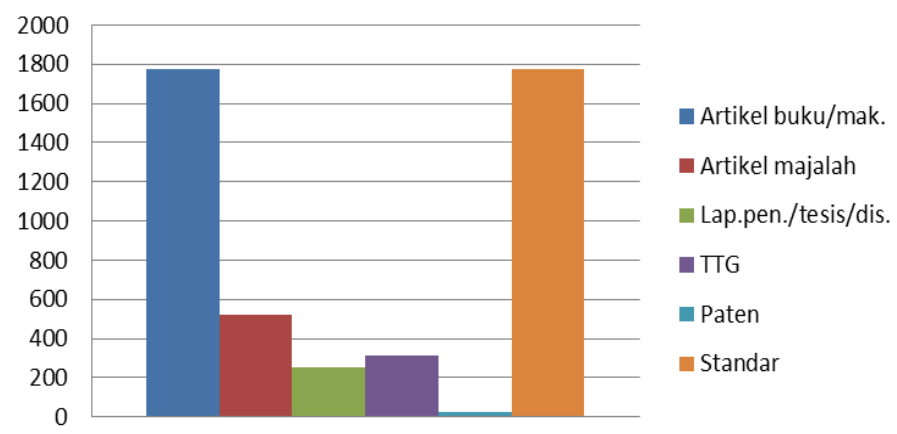

Gambar 1. Grafik permintaan informasi bidang Iptek tahun $2011-2017$

Berdasarkan Tabel 1 diketahui tren kebutuhan informasi standar tahun 2011 adalah ASTM (40,14\%), IEC (16,85\%), JIS (10,75\%), ISO (10,04\%), BS (5,02\%), SNI (3,58\%). Tren kebutuhan informasi standar tahun 2012 adalah ASTM (50,66\%), JIS (24,67\%), SNI $(13,66 \%)$, ISO (10,57\%). Tren kebutuhan informasi standar tahun 2013 adalah ASTM $(61,19 \%)$, JIS $(12,44 \%)$, SNI $(6,97 \%)$, ISO (4,48\%). Tren kebutuhan informasi standar tahun 2014 adalah ASTM (33,59\%), ISO (15,25\%), DIN (14,47\%), JIS (10,08\%), UIC $(9,56 \%)$, BS $(6,46 \%)$, SNI (3,88\%). Tren kebutuhan informasi standar tahun 2015 adalah ASTM $(39,02 \%)$, SNI (21,95\%), ISO (18,70\%), JIS (15,45\%). Tren kebutuhan informasi standar tahun 2016 adalah JIS (41,38\%), BS (27,85\%), ASTM (18,30\%), ISO (5,04\%), SNI $(3,18 \%)$. Tren kebutuhan informasi standar tahun 2017 adalah JIS (34,25\%), ASTM (31,49\%), SNI (9,39\%), BS (6,08\%), ISO (3,87\%).

Dalam kurun waktu tahun 2011 - 2017, kebutuhan informasi standar paling banyak pada tahun 2014, yaitu sebanyak 387 judul (21,80\%). Jenis standar yang paling banyak diminta terjadi pada tahun 2011, yaitu ASTM, dengan jumlah 130 permintaan $(33,59 \%)$ dan yang paling sedikit terjadi pada tahun 2015, dengan jumlah 123 permintaan $(6,93 \%)$. Hal tersebut dapat dilihat pada Gambar 2.

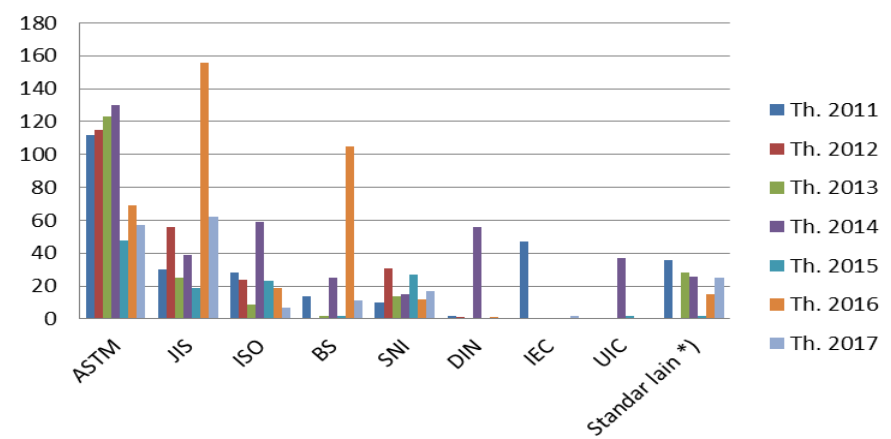

Gambar 2. Grafik kebutuhan informasi standar di Kawasan Puspiptek Serpong 
Gambar 2 dan Tabel 2 menunjukkan bahwa kebutuhan standar ASTM di Kawasan Puspiptek setiap tahunnya relatif tinggi. ASTM Internasional merupakan salah satu organisasi pengembangan standar sukarela terbesar di dunia, yang mengembangkan standardisasi teknis untuk material, produk, sistem dan jasa. ASTM Internasional berpusat di Amerika Serikat (ASTM International - Standards Worldwide, 2018). Permintaan standar ASTM selama tahun 2011 - 2017 sebanyak 654 nomor (36,85\%) dari keseluruhan jumlah permintaan informasi standar. Sedangkan kebutuhan standar JIS melonjak tinggi pada tahun 2016, dengan jumlah 156 permintaan (41,38\%) dan British Standard sejumlah 105 permintaan (27,85\%). dari total permintaan standar tahun 2016.

Tabel 2. Kebutuhan Informasi Standar di Kawasan Puspiptek Serpong Tahun 2011 - 2017

\begin{tabular}{|l|c|c|}
\hline \multicolumn{1}{|c|}{ Jenis Standar } & Jumlah Permintaan & Persentase (\%) \\
\hline ASTM & 654 & 36,85 \\
\hline JIS & 387 & 21,80 \\
\hline ISO & 169 & 9,52 \\
\hline BS & 159 & 8,96 \\
\hline SNI & 126 & 7,10 \\
\hline DIN & 60 & 3,38 \\
\hline IEC & 49 & 2,76 \\
\hline UIC & 39 & 2,20 \\
\hline Standar lain & 132 & 7,44 \\
\hline Jumlah & $\mathbf{1 7 7 5}$ & $\mathbf{1 0 0}$ \\
\hline
\end{tabular}

Permintaan dokumen standar di urutan kedua yaitu JIS. JIS merupakan standar yang digunakan untuk kegiatan industri di Jepang. Dalam kurun waktu 2011 - 2017, jumlah permintaan JIS sebanyak 387 nomor (21,80\%). Jumlah permintaan dokumen pada urutan ketiga adalah standar ISO. ISO diciptakan atas dasar perjanjian internasional, untuk membantu dalam mengatasi hambatan dalam perdagangan internasional. Karena singkatan dari masingmasing bahasa berbeda (IOS dalam bahasa Inggris dan OIN dalam bahasa Perancis), para pendirinya menggunakan singkatan ISO (ISO - International Organization for Standardization, 2018). Dalam kurun waktu 2011 - 2017, jumlah permintaan ISO sebanyak 169 nomor $(9,52 \%)$.

Permintaan dokumen standar di urutan keempat adalah standar British, dengan jumlah 159 nomor (8,96\%) pada tahun 2011 - 2017. British Standards Institution (BSI) merupakan badan standar nasional Kerajaan Inggris. BSI menghasilkan standar teknis untuk berbagai produk dan layanan, memasok layanan sertifikasi dan layanan standar kepada bisnis. BSI juga merupakan kepentingan nasional dan sosial dari negara Inggris di semua organisasi standardisasi Eropa dan internasional dalam pengembangan informasi bisnis lembaga British dari semua sektor (British Standards Institution, 2018). Permintaan dokumen standar pada urutan kelima adalah SNI, dengan jumlah permintaan 126 nomor (7,10\%). SNI adalah satusatunya standar teknis yang berlaku secara nasional di Indonesia yang dirumuskan oleh Komite Teknis Perumusan SNI dan ditetapkan oleh Badan Standardisasi Nasional (BSN). BSN merupakan Lembaga Pemerintah Non-Kementerian Indonesia dengan tugas pokok mengembangkan dan membina kegiatan standardisasi di Indonesia. Dalam melaksanakan tugasnya, BSN berpedoman pada Peraturan Pemerintah No.102 Tahun 2000 tentang Standardisasi Nasional. Penerapan SNI pada dasarnya bersifat sukarela. Namun, untuk keperluan melindungi kepentingan umum, keamanan negara, perkembangan ekonomi 
nasional, dan pelestarian fungsi lingkungan hidup, pemerintah dapat memberlakukan SNI tertentu secara wajib (Badan Standardisasi Nasional, 2018).

Permintaan dokumen standar pada urutan keenam adalah DIN, dengan jumlah permintaan 60 nomor (3,38\%). DIN merupakan hasil kerja di tingkat nasional, Eropa dan/atau internasional. Siapapun dapat mengajukan proposal untuk standar baru DIN. Setelah diterima, proyek standar yang sesuai dilakukan penetapan aturan prosedur oleh Komite Standar DIN. Semua pemangku kepentingan dapat berpartisipasi dalam pekerjaan ini, termasuk produsen, konsumen, bisnis, lembaga penelitian, otoritas publik, dan badan pengujian (DIN - German National Standards, 2018). Permintaan dokumen standar pada urutan kedelapan adalah standar IEC, dengan jumlah permintaan 49 nomor $(2,76 \%)$. IEC adalah organisasi terkemuka di dunia, yang menciptakan dan mengeluarkan standar internasional untuk listrik, elektronik dan teknologi lain yang terkait yang secara umum dikenal "elektroteknologi". IEC adalah satu dari tiga organisasi global sejenis (IEC, ISO, ITU) yang mengembangkan standar internasional untuk dunia. Standar IEC meliputi berbagai teknologi dari pembangkitan, transmisi, dan distribusi listrik hingga perlengkapan rumah tangga dan perlengkapan kantor, semikonduktor, serat optik, baterai, tenaga surya, nanoteknologi dan tenaga air laut. Di berbagai perusahaan listrik dan elektronik dapat ditemukan IEC, yang mempromosikan keselamatan dan kinerja, lingkungan, efisiensi energi listrik dan energi terbarukan (IEC - International Electrotechnical Commission, 2018).

Permintaan dokumen standar pada urutan kesembilan adalah standar UIC, dengan jumlah permintaan 39 nomor $(2,20 \%)$. UIC merupakan asosiasi profesional di dunia yang mewakili sektor perkeretaapian dan mempromosikan transportasi kereta api. UIC juga mengawasi kriteria keselamatan seperti "interlocking plant" dan rem otomatis. UIC merupakan perusahaan dengan anggota tingkat internasional, memimpin sektor yang inovatif dan dinamis, membantu anggota menemukan kesuksesan dan peluang secara terus-menerus. Misi UIC adalah mempromosikan transportasi kereta api di tingkat dunia dan memenuhi tantangan mobilitas dan pembangunan berkelanjutan (UIC - International Union of Railways, 2018).

Pada kajian ini permintaan dokumen standar di Kawasan Puspiptek Serpong jumlahnya relatif sedikit - dimasukkan ke kelompok "standar lain". Jumlah permintaan dokumen standar lain dalam kurun waktu tahun 2011 - 2017 sebanyak 132 nomor (7,44\%), terdiri atas: AS (Australian Standard), Volvo, AWS (American Welding Society), SAE (Society of Automotive Engineers), SPLN (Standar PLN), GMW (General Motors Worldwide), NACE (The National Association of Corrosion Engineers), AASHTO (American Association of State Highway and Transportation Officials), SS, AAR (Association of American Railroads), CS, ITU (International Telecommunication Union), TIS (Thai Industrial Standard), AOCS (American Oil Chemists' Society), IATF (International Automotive Task Force), dan NZS (New Zealand Standard). Hal tersebut dapat dilihat pada Gambar 3. 


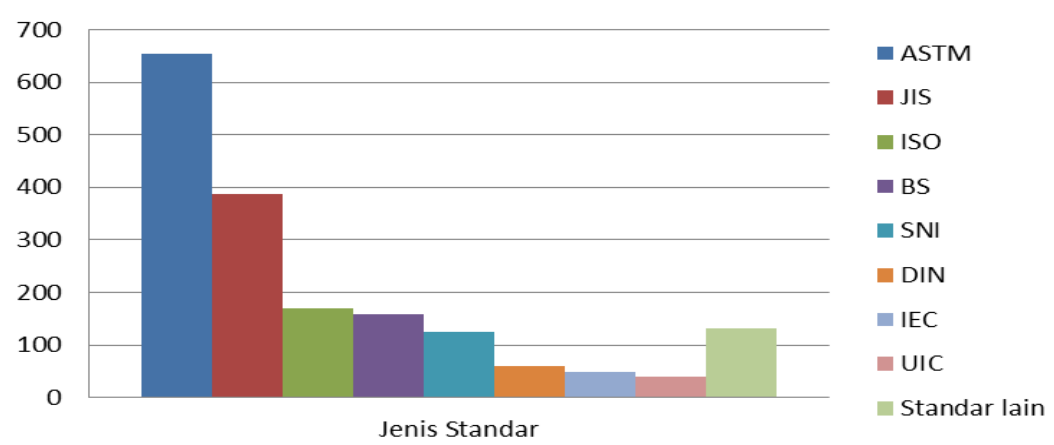

Gambar 3. Permintaan informasi dokumen standar di Kawasan Puspiptek Serpong (2011 - 2017)

\subsection{Kebutuhan Informasi Standar Berdasarkan Klasifikasi}

\subsubsection{ASTM}

ASTM membagi informasi standarnya berdasarkan 7 bidang klasifikasi, yaitu klasifikasi A - Ferrous Metals; B - Nonferrous metals; C - Cementitious, Ceramic, Concrete, and Masonry Materials; D - Miscellaneous Materials; E - Miscellaneous Subjects; F - Materials for Specific Applications; G - Corrosion, Deterioration, and Degradation of materials (ASTM International - Standards Worldwide, 2018). Dalam kurun waktu tahun 2011 - 2017, jumlah permintaan standar ASTM sebanyak 654 nomor (36,85\%). Hal tersebut dapat dilihat pada Tabel 3.

Tabel 3. Klasifikasi Permintaan Dokumen ASTM Tahun 2011 - 2017

\begin{tabular}{|c|c|c|}
\hline Bidang Klasifikasi & $\begin{array}{c}\text { Jumlah } \\
\text { Permintaan }\end{array}$ & $\begin{array}{c}\text { Persentase } \\
(\%)\end{array}$ \\
\hline $\mathrm{D}$-Miscellaneous Material & 307 & 46,94 \\
\hline E-Miscellaneous Subjects & 151 & 23,09 \\
\hline $\mathrm{C}-$ Cementious, Ceramic, Concrete, and Masonry Material & 84 & 12,84 \\
\hline $\mathrm{F}$ - Materials for Specific Applications & 54 & 8,26 \\
\hline $\mathrm{G}-$ Corrosion, Deterioration, and Degradation of Materials & 29 & 4,43 \\
\hline B - Nonferrous Metals & 18 & 2,75 \\
\hline A - Ferrous Metals & 11 & 1,68 \\
\hline Total & 654 & 100 \\
\hline
\end{tabular}

Berdasarkan Tabel 3 terlihat bahwa subjek ASTM yang paling banyak diminta dalam kurun waktu tersebut adalah Kelompok D - Miscellaneous Material (307 nomor atau 46,94\%). Kemudian diikuti oleh Kelompok E - Miscellaneous Subjects (151 nomor atau 23,09\%); Kelompok C - Cementious, Ceramic, Concrete, and Masonry Material (84 nomor atau 12,84\%); Kelompok F - Materials for Specific Applications (54 nomor atau 8,26\%); dan klasifikasi A - Ferrous Metals; B - Nonferrous Metals, dan G - Corrosin, Deterioration, and Degradation of Materials relatif sedikit $(<5 \%)$.

\subsubsection{JIS}

JIS membagi informasi standarnya menjadi 19 bidang klasifikasi, yaitu klasifikasi A Civil Engineering and Architecture; B - Mechanical Engineering; C - Electronic and Electrical Engineering; D - Automotive Engineering; E - Railway Engineering; F - Ship Building; G - Ferrous Materials and Metallurgy; H - Nonferrous Materials and Metallurgy; K - Chemical Engineering; L - Textile Engineering; M - Mining; P - Pulp and Paper; Q - Management System; R - Ceramics; S - Domestic Wares; T - Medical 
Equipment and Safety Appliances; W - Aircraft and Aviation; X - Information Processing; Z - Miscellaneous (JIS - Japanese Industrial Standards, 2018). Dalam kurun waktu tahun 2011 - 2017, jumlah permintaan JIS sebanyak 387 nomor (21,80\%) ada 11 bidang (Tabel 4).

Tabel 4. Klasifikasi Permintaan Dokumen JIS Tahun 2011 - 2017

\begin{tabular}{|c|c|c|}
\hline Bidang Klasifikasi & $\begin{array}{c}\text { Jumlah } \\
\text { Permintaan }\end{array}$ & $\begin{array}{c}\text { Persentase } \\
(\%)\end{array}$ \\
\hline E-Railway Engineering & 155 & 40,05 \\
\hline $\mathrm{K}$ - Chemical Engineering & 94 & 24,29 \\
\hline B - Mechanical Engineering & 56 & 14,47 \\
\hline $\mathrm{Z}-$ Miscellaneous & 27 & 6,98 \\
\hline $\mathrm{H}-$ Nonferrous Materials and Metallurgy & 16 & 4,13 \\
\hline $\mathrm{G}-$ Ferrous Materials and Metallurgy & 13 & 3,36 \\
\hline A - Civil Engineering and Architecture & 7 & 1,81 \\
\hline $\mathrm{D}$ - Automotive Engineering & 6 & 1,55 \\
\hline $\mathrm{M}-$ Mining & 6 & 1,55 \\
\hline $\mathrm{C}-$ Electronic and Electrical Engineering & 4 & 1,03 \\
\hline $\mathrm{R}-$ Ceramics & 3 & 0,78 \\
\hline Total & 387 & 100 \\
\hline
\end{tabular}

Berdasarkan Tabel 4 terlihat bahwa subjek klasifikasi JIS yang paling banyak diminta dalam kurun waktu tersebut adalah Klasifikasi E - Railway Engineering (155 nomor atau 40,05\%). Kemudian diikuti oleh kelompok klasifikasi K - Chemical Engineering (94 nomor atau 24,29\%); Kelompok B - Mechanical Engineering (56 nomor atau 14,47\%); Kelompok Z Miscellaneous (27 nomor atau 6,98\%); dan Kelompok H - Nonferrous Materials and Metallurgy, G - Ferrous Materials and Metallurgy, A - Civil Engineering and Architecture, $\mathrm{D}$ - Automotive Engineering, M - Mining, C - Electronic and Electrical Engineering, $\mathrm{R}$ Ceramics, masing-masing relatif sedikit $(<5 \%)$.

\subsubsection{ISO}

ISO mengelompokkan standar berdasarkan International Classification Standard - ICS, yang mencakup 40 bidang klasifikasi, yaitu: 01 - Generalities, Terminology, Standardization, Documentation; 03 - Services, Company Organization, Management and Quality, Administration, Transport, Sociology; 07 - Natural and Applied Sciences; 11 Health Care Technology; 13 - Environment, Health Protection, Safety; 17 - Metrology and Measurement, Physical Phenomena; 19 - Testing; 21 - Mechanical Systems and Components for General Use; 23 - Fluid Systems and Components for General Use; 25 Manufacturing Engineering; 27 - Energy and Heat Transfer Engineering; 29 - Electrical Engineering; 31 - Electronics; 33 - Telecommunications, Audio and Video Engineering; 35 - Information Technology; 37 - Image Technology; 39 - Precision Mechanics, Jewellery; 43 - Road Vehicles Engineering; 45 - Railway Engineering; 47 - Shipbuilding and Marine Structures; 49 - Aircraft and Space Vehicle Engineering; 53 - Materials Handling Equipment; 55 - Packaging and Distribution of Goods; 59 - Textile and Leather Technology; 61 - Clothing Industry; 65 - Agriculture; 67 - Food Technology; 71 - Chemical Technology; 73 - Mining and Minerals; 75 - Petroleum and Related Technologies; 77 Metallurgy; 79 - Wood Technology; 81 - Glass and Ceramics Industries; 83 - Rubber and Plastic Industries; 85 - Paper Technology; 87 - Paint and colour Industries; 91 Construction Materials and Building; 93 - Civil Engineering; 95 - Military Affairs, Military 
Engineering, Weapons; 97 - Domestic and Commercial Equipment. Entertainment, Sports. (ISO - International Organization for Standardization, 2018).

Jumlah permintaan ISO selama dalam tahun 2011 - 2017 sebanyak 169 nomor $(9,52 \%)$ yang meliputi 14 bidang (Tabel 5).

Tabel 5. Klasifikasi Permintaan Standar ISO Tahun 2011 - 2017

\begin{tabular}{|l|c|c|}
\hline \multicolumn{1}{|c|}{ Bidang Klasifikasi } & $\begin{array}{c}\text { Jumlah } \\
\text { Permintaan }\end{array}$ & $\begin{array}{c}\text { Persentase } \\
(\%)\end{array}$ \\
\hline $83-$ Rubber and Plastic Industries & 85 & 50,30 \\
\hline $77-$ Metallurgy & 20 & 11,83 \\
\hline $43-$ Road vehicles Engineering & 16 & 9,47 \\
\hline $23-$ Fluid Systems and Components for General Use & 15 & 8,88 \\
\hline $13-$ Environment, Health Protection, Safety & 9 & 5,33 \\
\hline $\begin{array}{l}\text { 03- Services, Company Organization, Management and } \\
\text { Quality, Administration, Transport, Sociology }\end{array}$ & 6 & 3,55 \\
\hline $35-$ Information Technology & 6 & 3,55 \\
\hline $25-$ Manufacturing Engineering & 2 & 1,18 \\
\hline $19-$ Testing & 2 & 1,18 \\
\hline $17-$ Metrology and Measurement, Physical & 2 & 1,18 \\
\hline $87-$ Paint and Colour Industries & 2 & 1,18 \\
\hline $27-$ Energy and Heat Transfer Engineering & 2 & 1,18 \\
\hline $59-$ Textile and Leather Technology & 1 & 0,59 \\
\hline 01- Generalities. Terminology. Standardization, Docu- \\
Mentation
\end{tabular}

Pada Tabel 5 terlihat bahwa standar ISO yang paling banyak diminta pada tahun 2011 2017 adalah bidang klasifikasi 83 - Rubber and Plastic Industries (85 nomor atau 50,30\%). Kemudian diikuti oleh bidang klasifikasi 77 - Metallurgy (20 nomor atau 11,83\%); 43 Road Vehicles Engineering (16 nomor atau 9,47\%); 23 - Fluid Systems and Components for General Use (15 nomor atau 8,88\%); 13 - Environment, Health Protection, Safety (9 nomor atau 5,33\%); dan bidang lain relatif sedikit $(<5 \%)$.

\subsubsection{British Standards}

British National Standards atau BS mengklasifikasi standar yang dipublikasikan dengan mengikuti International Classification Standard - ICS, yang mencakup 27 bidang klasifikasi yaitu: Food Technology; Information Technology; Environment, Health Protection, Safety; Domestic and Commercial Equipment, Entertainment, Sports; Aircraft and Space Vehicle Engineering; Chemical Technology; Metrology and Measurement, Physical Phenomena; Electronics; Natural and Applied Sciences; Construction Materials and Building; Petroleum and Related Technologies; Telecommunications, Audio and Video Engineering; Electrical Engineering; Energy and Heat Transfer Engineering; Agriculture; Road Vehicles Engineering; Packaging and Distribution of Goods; Health Care Technology; Civil Engineering; Rubber and Plastic Industries; Shipbuilding and Marine Structures; Railway Engineering; Image Technology; Services, Company Organization, Management and Quality, Administration, Transport, Sociology; Generalities, Terminology, Standardization, Documentation; Metallurgy; Clothing Industry (British Standards Institution - BSI, 2018). 
Dalam tahun 2011 - 2017, permintaan BS sebanyak 159 nomor (8,96\%) yang mencakup 16 bidang (Tabel 6).

Tabel 6. Klasifikasi Permintaan Dokumen BS Tahun 2011 - 2017

\begin{tabular}{|c|c|c|}
\hline Bidang Klasifikasi & $\begin{array}{l}\text { Jumlah } \\
\text { Permintaan }\end{array}$ & $\begin{array}{l}\text { Persentase } \\
\quad(\%)\end{array}$ \\
\hline 65 - Agriculture & 31 & 19,50 \\
\hline $91-$ Construction Materials and Building & 30 & 18,87 \\
\hline $71-$ Chemical Technology & 25 & 15,72 \\
\hline 73 - Mining and Minerals & 8 & 5,03 \\
\hline 93 - Civil Engineering & 8 & 5,03 \\
\hline 13 - Environment Health Protection, Safety & 8 & 5,03 \\
\hline 27 - Energy and Heat Transfer Engineering & 7 & 4,40 \\
\hline $\begin{array}{l}97 \text { - Domestic and Commercial Equipment, } \\
\text { Entertainment, Sports }\end{array}$ & 7 & 4,40 \\
\hline 75 - Petroleum and Related Technologies & 6 & 3,77 \\
\hline 25 - Manufacturing Engineering & 6 & 3,77 \\
\hline 45 - Railway Engineering & 6 & 3,77 \\
\hline 17 - Metrology and Measurement, Physical Phenomena & 6 & 3,77 \\
\hline 83 - Rubber and Plastic Industries & 5 & 3,14 \\
\hline 77 - Metallurgy & 3 & 1,89 \\
\hline 23 - Fluid Systems and Components for General Use & 2 & 1,26 \\
\hline $29-$ Electrical Engineering & 1 & 0,63 \\
\hline $\begin{array}{ll}\text { Total } \\
\end{array}$ & 159 & 100 \\
\hline
\end{tabular}

Pada Tabel 6 terlihat bahwa permintaan BS paling banyak terjadi pada bidang klasifikasi 65 - Agriculture (31 nomor atau 19,50\%). Kemudian diikuti oleh bidang klasifikasi 91 Construction Materials and Building (30 nomor atau 18,87\%); 71 - Chemical Technology (25 nomor atau 15,72\%); 73 - Mining and Minerals; 93 - Civil Engineering; 13 Environment. Health Protection, Safety (8 nomor atau 5,03\%); dan bidang lain relatif sedikit $(<5 \%)$.

\subsubsection{Standar Nasional Indonesia}

BSN mengklasifikasi SNI berdasarkan International Classification Standard - ICS. Dalam tahun 2011 - 2017, jumlah permintaan SNI sebanyak 126 nomor yang mencakup 13 bidang klasifikasi (Tabel 7).

Tabel 7. Klasifikasi Permintaan Dokumen SNI Tahun 2011 - 2017

\begin{tabular}{|l|c|c|}
\hline \multicolumn{1}{|c|}{ Bidang Klasifikasi } & $\begin{array}{c}\text { Jumlah } \\
\text { Permintaan }\end{array}$ & $\begin{array}{c}\text { Persentase } \\
(\%)\end{array}$ \\
\hline 77 - Metallurgy & 39 & 30,95 \\
\hline 67- Food Technology & 17 & 13,49 \\
\hline 91 - Construction Materials and Building & 14 & 11,11 \\
\hline 21 - Mechanical Systems and Components for General Use & 11 & 8,73 \\
\hline 83- Rubber and Plastic Industries & 10 & 7,94 \\
\hline $\begin{array}{c}\text { 03 - Services, Company Organization, Management and } \\
\text { Quality, Administration, Transport, Sociology }\end{array}$ & 9 & 7,14 \\
\hline
\end{tabular}




\begin{tabular}{|c|c|c|}
\hline 13 - Environment, Health Protection, Safety & 8 & 6,35 \\
\hline 23 - Fluid Systems and Components for General Use & 5 & 3,97 \\
\hline $65-$ Agriculture & 4 & 3,17 \\
\hline 75 - Petroleum and Related Technologies & 3 & 2,38 \\
\hline $31-$ Electronics & 2 & 1,59 \\
\hline $59-$ Textile and Leather Technology & 2 & 1,59 \\
\hline 73 - Mining and Minerals & 2 & 1,59 \\
\hline 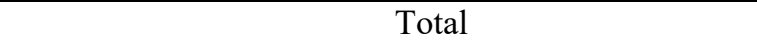 & 126 & 100 \\
\hline
\end{tabular}

Pada Tabel 7 terlihat bahwa permintaan SNI yang paling banyak yaitu bidang klasifikasi 77 - Metallurgy (39 nomor atau 30,95\%). Kemudian diikuti oleh bidang klasifikasi 67 - Food Technology (17 nomor atau 13,49\%); 91 - Construction Materials and Building (14 nomor atau 11,11\%); 21 - Mechanical Systems and Components for General Use (11 nomor atau 8,73\%); 83 - Rubber and Plastic Industries (10 nomor atau 7,94\%); 03 - Services, Company Organization, Management and Quality, Administration, Transport, Sociology (9 nomor atau 7,14\%); 13 - Environment, Health Protection, Safety (8 nomor atau 6,35\%); dan 23 - Fluid Systems and Components for General Use; 65 -Agriculture; 75 -Petroleum and Related Technologies; 31 - Electronics; 59 - Textile and Leather Technology; 73 - Mining and Minerals, masing-masing permintaannya relatif sedikit $(<5 \%)$.

\subsubsection{DIN - German National Standards}

Pada tahun 2011 - 2017, permintaan standar DIN sebanyak 60 nomor (3,38\%) yang mencakup 7 bidang (Tabel 8).

Tabel 8. Klasifikasi Permintaan Dokumen DIN Tahun 2011 - 2017

\begin{tabular}{|c|c|c|}
\hline Bidang Klasifikasi & $\begin{array}{c}\text { Jumlah } \\
\text { Permintaan }\end{array}$ & $\begin{array}{c}\text { Persentase } \\
(\%)\end{array}$ \\
\hline 83 - Rubber and Plastic Industries & 23 & 38,33 \\
\hline 87 - Paint and Colour Industries & 17 & 28,33 \\
\hline 91 - Construction Materials and Building & 8 & 13,33 \\
\hline $77-$ Metallurgy & 7 & 11,67 \\
\hline $\begin{array}{l}21 \text { - Mechanical Systems and Components for General } \\
\text { Use }\end{array}$ & 2 & 3,33 \\
\hline 17 - Metrology and Measurement, Physical Phenomena & 2 & 3,33 \\
\hline $59-$ Textile and Leather Technology & 1 & 1,67 \\
\hline Total & 60 & 100 \\
\hline
\end{tabular}

Pada Tabel 8 terlihat bahwa permintaan DIN paling banyak diminta adalah bidang klasifikasi 83 - Rubber and Plastic Industries (23 nomor atau 38,33\%). Kemudian diikuti oleh bidang klasifikasi 87 - Paint and Colour Industries (17 nomor atau 28,33\%); 91 - Construction Materials and Building (8 nomor atau 13,33\%); 77 - Metallurgy (7 nomor atau 11,67\%); dan 21 - Mechanical Systems and Components for General Use; 17 - Metrology and Measurement, Physical Phenomena; 59 - Textile and Leather Technology, masing-masing permintaannya relatif sedikit $(<5 \%)$.

\subsubsection{International Electrotechnical Commission}

IEC merupakan organisasi terkemuka di dunia, yang menciptakan dan mengeluarkan standar internasional untuk listrik, elektronik dan teknologi lain yang terkait yang secara 
umum dikenal dengan "elektroteknologi". IEC adalah satu dari tiga organisasi global sejenis yaitu IEC, ISO, dan ITU. Bidang klasifikasi IEC dipublikasikan berdasarkan (IEC International Electrotechnical Commission, 2018). Pada tahun 2011 - 2017, permintaan standar IEC sebanyak 49 nomor yang mencakup 3 bidang (Tabel 9).

Tabel 9. Klasifikasi Permintaan Dokumen Standar IEC Tahun 2011 - 2017

\begin{tabular}{|c|c|c|}
\hline Bidang Klasifikasi & $\begin{array}{c}\text { Jumlah } \\
\text { Permintaan }\end{array}$ & $\begin{array}{c}\text { Persentase } \\
(\%)\end{array}$ \\
\hline $\begin{array}{c}29-\text { Electrical Engineering (Wires, Insulators, Power } \\
\text { Transmission and Distribution Lines) }\end{array}$ & 24 & 48,98 \\
\hline $19-$ Testing (Environmental Testing) & 16 & 32,65 \\
\hline $33-$ Telecommunications, Audio, and Video Engineering & 9 & 18,37 \\
\hline Total & 49 & 100 \\
\hline
\end{tabular}

Pada Tabel 9 diketahui bahwa Standar IEC yang paling banyak diminta adalah 29 Electrical Engineering (24 nomor atau 48,98\%). Kemudian diikuti oleh 19 - Testing, Environmental Testing (16 nomor atau 32,65\%); 33 - Telecommunications, Audio, and Video Engineering (9 nomor atau 18,37\%).

\subsubsection{International Union of Railways}

UIC - International Railway Union (dalam bahasa Perancis "Union Internationale Des Chemins De Fer", dalam bahasa Inggris "International Union of Railways") adalah asosiasi profesional di seluruh dunia yang mewakili sektor perkeretaapian dan mempromosikan transportasi kereta api (UIC - International Union of Railways, 2018). Pada tahun 2011 2017 jumlah permintaan standard UIC sebanyak 39 judul dan dokumen tersebut seluruhnya dibutuhkan oleh Balai Besar Teknologi Kekuatan Struktur (B2TKS) - BPPT.

\subsubsection{Standar Lain}

Dokumen standar yang dimasukkan ke dalam kelompok "standar lain" antara lain: AS (Australia Standard), AAR (The Association of American Railroads), AASHTO (American Association of State Highway and Transportation Officials), AOCS (American Oil Chemists' Society), AWS (American Welding Society), CS, GMW (General Motors Worldwide), IATF (International Automotive Task Force), ITU (International Telecommunication Union), NACE (The National Association of Corrosion Engineers), NZS (New Zealand Standard), SAE (Society of Automotive Engineers), SPLN (Standar PLN), SS, TIS (Thai Industrial Standard), dan Volvo. Jumlah permintaan dokumen standar tersebut dalam kurun waktu tahun 2011 2017 relatif sedikit yakni masing-masing hanya $<1 \%$ sehingga tidak dilakukan analisis lebih lanjut.

\section{KESIMPULAN}

Berdasarkan hasil dan pembahasan dapat disimpulkan bahwa: (1) jenis informasi standar yang diperlukan di Kawasan Puspiptek Serpong yaitu ASTM, JIS, ISO, BS, SNI, DIN, IEC, UIC, dan standar lain seperti AS, AAR, AASHTO, AOCS, AWS, CS, GMW, IATF, ITU, NACE, NZS, SAE, SPLN, SS, TIS, dan Volvo; (2) berdasarkan klasifikasi standar, terlihat bahwa untu: a) ASTM, klasifikasi D (Miscellaneous Material); E (Miscellaneous Subjects); C (Cementious, Ceramic, Concrete, and Masonry Material); F (Materials for 
Specific Applications); b) JIS, klasifikasi E (Railway Engineering); K (Chemical Engineering); B (Mechanical Engineering); c) ISO, klasifikasi 83 (Rubber and Plastic Industries); 77 (Metallurgy); 43 (Road Vehicles Engineering); 23 (Fluid Systems and Components for General Use); 13 (Environment, Health Protection, Safety); d) BS, klasifikasi 65 (Agriculture); 91 (Construction Materials and Building); 71 (Chemical technology); 73 (Mining and Minerals); 93 (Civil Engineering); 13 (Environment, Health protection. Safety); e) SNI, klasifikasi 77 (Metallurgy); 67 (Food Technology); 91 (Construction Materials and Building); 21 (Mechanical Systems and Components for General Use); 83 (Rubber and Plastic Industries); 03 (Services, Company Organization, Management and Quality, Administration, Transport, Sociology); 13 (Environment, Health Protection, Safety); f) DIN, klasifikasi 83 (Rubber and Plastic Industries); 87 (Paint and Colour Industries); 91 (Construction Materials and Building); 77 (Metallurgy); g). IEC, klasifikasi 29 (Electrical Engineering); 19 (Testing/Environmental Testing); 33 (Telecommunications, Audio and Video Engineering). Hasil kajian ini diharapkan dapat menjadi bahan pertimbangan bagi para pengambil keputusan dalam hal pengadaan dan penyediaan dokumen standar di kawasan Puspiptek Serpong. 


\section{DAFTAR PUSTAKA}

ASTM International - Standards Worldwide. 2018. Di https://www.astm.org/.

Badan Standardisasi Nasional/BSN. 2018. Di http://www.bsn.go.id/.

British Standards Institution/BSI. 2018. Di https://www.bsigroup.com/.

DIN - German National Standards. 2018. Di https://www.din.de/en.

IEC - International Electrotechnical Commission. 2018. Di https://www.iec.ch/.

ISO - International Organization for Standardization. 2018. Di https://www.iso.org/home.html.

JIS - Japanese Industrial Standards. 2018. Di https://www.jsa.or.jp/en/.

Peraturan Pemerintah RI No.102 Tahun 2000 Tentang Standardisasi Nasional. 2000. Jakarta.

Rahartri. 2017. Pedoman Penelusuran Informasi Standard Teknis. Jakarta: PDII LIPI.

UIC - International Union of Railways. 2018. https://uic.org/.

Undang - Undang RI No.20 Tahun 2014 Tentang Standardisasi dan Penilaian Kesesuaian. 2014. Jakarta.

Wikipedia. 2018. Pusat Penelitian Ilmu Pengetahuan dan Teknologi. Di https://id.wikipedia.org/wiki/Pusat_Penelitian_Ilmu_Pengetahuan_dan_Teknologi. 